14. Shakhrai V. M. (2005). Sotsialno-tsinnisnyi aspekt diialnosti dytiachoho teatru : monohrafiia [The socially-valuable aspect of childish theater: a monograph]. Bila Tserkva : Vyd-vo Semenka S. 172 s. [in Ukrainian]

\title{
Sheredko I. H. Formation of valuable attitudes to the Motherland in adolescent children as a problem of modern education
}

The article reveals the importance of forming a valuable attitude towards the Motherland among adolescent children in the context of socio-cultural and educational tasks. The essence of such concepts as "valuable attitude», "Motherland» is clarified. The author's definition of the concept of valuable attitude towards the Motherland in younger students as an emotional and meaningful connection of children with the Motherland is offered. It is reflected in the deep feelings for the Motherland and in the children's awareness of the importance of the Motherland for their lives. The position of well-known native teachers (G. Vashchenko, S. Rusova, K. Ushinsky) is considered, regarding the formation of respect for the native people and the country, which is relevant in the modern educational process. It is emphasized that the primary school age is a sensitive period for forming a valuable attitude towards the Motherland, due to the peculiarities of the emotional sphere of children of this age. The components of the formation process of valuable attitude towards the Motherland from younger students are determined (cognitive, emotional, activity) and pedagogical conditions for its implementation: the use of forms and methods of education and training that would contribute to the development of emotional and sensual sphere of children; organization of activities of pupils, based on material related to the history, culture of their native country; cooperation in the formation of a valuable attitude towards the Motherland among younger students of educational institutions and families, etc. It is concluded that there is a need for a systematic approach to solving the problem of formation of a value attitude towards the Motherland in children of primary school age.

Key words: valuable attitude, Motherland, primary school age, children, formation, components, educational problem, educational process, pedagogical conditions.

УДК 378.016:[80+33+002.1]

DOI https://doi.org/10.31392/2311-5491/2019-70.66

Якубовська М. С., Будзінська В. М.

\section{КОНЦЕПТУАЛЬНО-ЕСТЕТИЧНІ ЗАСАДИ НАУКОВОЇ ШКОЛИ АКАДЕМІКА Н. Г. НИЧКАЛО: КУЛЬТУРОЛОГІЧНИЙ АСПЕКТ}

На прикладі дослідження кониептуальних засад науково-педагогічної школи академіка Н. Г. Ничкало вивчасться система концептуально-педагогічних засад науково-педагогічної школи академіка Н. Г. Ничкало. Проведене дослідження дає можливість стверджувати, щзо важливим засобом формування особистості сучасного фахівия є культурологічний складник. Дослідження алгоритму науково-теоретичних аспектів інноваційних змін у системі вищої школи показує, щзо від розвитку інноваційного складника сучасних закладів вищої освіти залежить гуманітарна безпека суспільства. Педагогіка, виконуючи свої історичні завдання, створює передумови для утвердження якісних інноваційних прочесів педагогічної взаємодії.

Входження України до світового освітнього та економічного співтовариства, глобалізація світової економіки викликає необхідність змін у характері професійної освіти (у ї̈ спрямованості, иілях, змісті), усе більш явно орієнтуючи ї̈ на творчий розвиток людини, на творчу ініціативу, самостійність, конкурентоздатність, мобільність майбутніх фахівиів.

На прикладі дослідження досвіду науково-педагогічної школи академіка Н. Г. Ничкало накреслюється алгоритм системних процесів, в основі яких лежить формування комунікативної компетентності студентів, системне й еволюиійне осмислення дискурсу сучасної освіти та забезпечення варіативних технологій культурологічної освіти студентів.

Для успішної реалізачії завдань сучасної особистісно зорієнтованої освіти важливим є формування культурологічної компетентності вихованців, яка становить основу гуманітарної безпеки сучасності, складовими частинами якоі є інформаційна та психологічна безпека сучасного суспільства. Гармонія соиіуму залежсть від гармонійного становлення особисті на всіх етапах навчальної діяльності. У даних процесах важливим є дослідження науково-теоретичних аспектів формування алгоритму інноваційних змін у системі сучасної освіти.

Ключові слова: культурологічна компетентність, культурологічний світогляд, науковий дискурс, інваріантність дискурсу, культурологічна свідомість, мистецтво спілкування, культурологічне середовище, психологічний захист особистості, комунікативна компетентність, парадигма культурної взаємодії.

Для успішної реалізації завдань сучасної особистісно зорієнтованої освіти важливим є формування культурологічної компетентності вихованців, яка становить основу гуманітарної безпеки сучасності, складовими частинами якої є інформаційна та психологічна безпека сучасного суспільства. Гармонія соціуму залежить від гармонійного становлення особисті на всіх етапах навчальної діяльності. У даних процесах важливим $\epsilon$ дослідження науково-теоретичних аспектів формування алгоритму інноваційних змін у системі сучасної освіти. Актуальним є також дослідження вироблення взаємозв'язку у системі формування комунікативної компетентності вихованців засобами художнього слова.

Метою статті є розгляд концептуальних засад науково-педагогічної школи академіка Н. Г. Ничкало.

Парадигма педагогіки життя як наукова система академіка Н. Г. Ничкало абсолютно інтегрального типу це багатоаспектне явище, яке тісно пов'язане з багатьма векторами сучасного розвитку як окремої людини, 
так і суспільства та загальних цивілізаційних процесів у цілому. Інтелектуали замислюються над векторами всезагального розвитку суспільства 3 огляду на прийдешні десятиліття. Зрозуміло, що якість людського капіталу визначає загальну спрямованість розвитку усіх векторів бізнесу і країни у цілому. Саме сьогодні закладаються основи буття людської цивілізації упродовж наступних десятиліть. Протягом декількох десятиліть академік Н. Г Ничкало досліджує і впроваджує у практику життя проблеми збереження, реформування та розвитку професійно-технічної освіти.

Методологія дослідження полягає в застосуванні компаративного, історико-логічного, синергетичного методів. Досліджується системне творення культурологічної моделі художнього тексту як цілісної функціональної єдності сутності художнього слова та навколишнього світу, розширення уявлень про синергетичну взаємодію між формуванням світогляду людини та гармонійним розвитком соціуму.

Про актуальність даної теми свідчить те, що нині існує низка досліджень проблеми формування культурологічного світогляду на всіх етапах освітньої діяльності. Формування культурологічної компетентності як інноваційної парадигми сучасності досліджують у своїх працях І. Д. Бех, В. П. Андрущенко, В. Г. Кремень, С. У. Гончаренко, І. А. Зязюн, Н. Г. Ничкало, В. О. Огнев’юк, Т. М. Герлянд, Л. Д. Герганов, М. Б. Євтух, Л. М. Єршова, А. А. Каленський, П. Г. Лузан, М. П. Пантюк, Л. А. Пригодій, В. Ф. Орлов, І. Д. Пасічник, Л. П. Пуховська, В. О. Радкевич, Л. М. Романишина, С. О. Сисоєва, М. Т. Теловата, О. І. Щербак, В. В. Ягупов та інші. Наукові проблеми культурологічної підготовки студентів досліджуються у сучасній педагогічній науці, професійній освіті, у стратегії духовно-екзистенційної боротьби за оновлення суспільства такими вченими, як В. П. Андрущенко, В. Г. Кремень, І. А. Зязюн, М. Б. Свтух, І. А Сліпухіна, Г. Л. Токмань, О. І. Шапран. Культурологія як наука може стати базою у формуванні психологічно-філософської парадигми становлення особистості сучасного фахівця.

I. Д. Бех накреслив алгоритм формування духовно-екзистенційних основ особистості у системному відтворенні від культури мислення до культури духовного переживання. У статті «Духовна особистість у контексті освітніх викликів» видатний учений I. Д. Бех наголошує: «Багатовікове відчуження людини від справжніх духовних цінностей призвело до кризових явищ, пов'язаних із занепадом духовно-моральних ідеалів, посиленням зла і насильства. Девальвація духовних цінностей суттєво вплинула на посилення тенденції зростання жорстокого індивідуалізму, прагматизму, зверхнього ставлення до інших людей та приниження їхньої гідності, зневаги до рідної культури та історико-культурних традицій» [3, с. 3].

Смисли народжуються у культурологічному просторі. Вони не тільки мисляться, а і творяться, чуттєво переживаються і тим формують духовний світ людської індивідуальності. У даному випадку маємо поєднання ірраціонального і раціонального начал.

Згідно 3 концептуальними засадами науково-педагогічної школи академіка Н. Г. Ничкало важливою умовою формування сучасного спеціаліста є поєднання професійної кваліфікації із засадами професійної соціологізації, успішне виконання якого передбачає поєднання формування особистості самого студента, розвитку його індивідуальних якостей і особливостей та засвоєння студентом знань стосовно конкретних технологій зі спеціальності, які в майбутньому стануть засобом і змістом його професійної діяльності.

Життя вимагає інтелектуально розвиненої особистості і водночас толерантної, відкритої до демократичного спілкування й розвитку в національному та міжнародному вимірі. На думку П. Юркевича [1, с. 145], поняття особистості пов'язане із поняттям душі, яка є іії підгрунтям, що знаходиться в глибині «Я», серця. Саме тому філософію українського народу вчений (за Г.Сковородою) називає філософією серця, тобто кордоцентризмом. Продовжуючи свої міркування, П. Юркевич робить висновок про те, що справжня сутність людини відкривається у внутрішньому досвіді, а виявляє себе в проявах особистості. Н. Грот [1, с. 245] звертає увагу на те, що треба визначити субстанціальність душі, iї позачасову природу. У філософському значенні людська особистість є носієм усесвітніх начал, одним з ії втілень. Г. Челпанов [1, с. 185] наполягає на тому, що справжнім предметом людинознавчих наук, зокрема філософії та психології, є система «суб' єкт субстанція». На особливу увагу заслуговують персоно-логічні розробки В. Зеньковського [1, с. 175], який створює концепцію розвитку особистості, iї соціальної та несоціальної детермінації.

У народі кажуть: «Знання без людяності - це меч у руках безумця». Саме тому вся національна система виховання пронизана гуманним ставленням до особистості вихованця. Видатний український філософ Г. Сковорода до цього додає: «Розум завжди любить до чогось братися, і коли він не матиме доброго, тоді звертатиметься до поганого».

Потреба в самоосвіті, в духовній самостійності, критична спрямованість мислення, іiї продуктивність у засвоєнні знань і людської культури - це риси, яких не вистачає нинішньому студентові. Висока цілісна культура створюється усім строєм суспільного життя. При цьому освіта і виховання слугують підгрунтям, яке формує тенденції гуманізації суспільства, його основні якісні характеристики, рівень цивілізованості. Основні принципи гуманітаризації є загальнонауковими. Це фундаментальність, системність у зв'язках 3 досягненнями природознавчих, технічних, технологічних наук, єдність історичного і логічного, національного і загальнолюдського, суспільного та особистого, теорії та практики навчання і виховання у творчій діяльності.

До головних структурних елементів культурологічної освіти належать світоглядно-філософський, соціально-політичний та соціологічний складники, історична, культурологічна, філологічна, етична та естетична освіта, українознавча підготовка, еколого-природнича, політекономічна, економічна та правова освіта, психолого-педагогічна підготовка, система знань та навичок, що забезпечують здоровий спосіб життя. 
Згідно з концептуальними засадами науково-педагогічної школи академіка Н. Г. Ничкало нормативнооцінна система інноваційних тенденцій сучасної професійної освіти є вагомим підгрунтям формування культурних традицій, цілісність яких зумовлює єдність історичної традиції та актуального творення парадигми інноваційних навчальних систем.

За словами російського мислителя О. Лосєва, міфічна відчуженість від дійсності є відчуженістю від смислу та ідеї повсякденного і звичайного життя. Сучасні письменники намагаються відновити цілісність спогаду, звести докупи все, що виникає у їхній пам'яті. Що глибше вони розкопують минуле, то більше усвідомлюють марність своїх зусиль, оскільки часова перспектива зруйнувала цілісність міфу.

У інтерв’ю, поміщеному у газеті «Високий замок», Адам Загайський вказував на філософську суть літератури: «Поезія відрізняється від філософії, але є й схожі риси. І поезія, і філософія намагаються зрозуміти світ. Справжня поезія намагається не лише висловити глибокі почуття, а й розібратися в них. Поезія оперує образами, а філософія - поняттями».

Спільне понятійне поле культури як духовної основи сучасного буття народу і $є$ тією фундаментальною структурованою парадигмою, яка створює основу для формування архетипу духовного порозуміння між народами. Дана парадигма є основою формування комунікативної компетентності сучасних фахівців.

Культурологічна теорія А. С. Канарського розглядає естетику як теорію чуттєвого пізнання, чуттєвого освоєння людиною дійсності: «Подлинная диалектика эстетического - это естественный исторический (и практический) процесс перехода объективности чувственного явления в субъективное состояние, самочувствие человека, другими словами, - это своеобразное дооформление бытия эстетического до уровня его завершения в человеческом переживании и утверждении» [1, с. 10]. Тобто чуттєвість виступає способом всебічного ставлення людини до світу. «Если мы примем позицию учёного, поясняющего, что эстетическое отношение рождается из чувственного небезразличия (равнодушие ведь не создаёт никакого отношения!), если мы согласимся с тем, что границы эстетической науки определяются именно таким пониманием чувственного, то отпадёт необходимость и в простом перечислении её (эстетики) задач, ведь эстетика - это и наука о прекрасном, и наука об искусстве, и наука о творчестве $<\ldots$.. «, - наголошує А. С. Канарський [1, с. 24]. Культурологічний процес у даному трактуванні співвідносний із естетикою, мистецтвом осягнення дійсності, що є важливою умовою у системі формування основ комунікативної компетенції засобами художньо-естетичного впливу.

Академік С. Гончаренко зазначає, що для сучасного освітнього простору характерна недостатня інтеграція, замкнутість окремих дисциплін, що заважає надбанню системних знань і фундаменталізації освіти $[1$, c. 6], тому еклектизм змісту освіти веде до безсистемності мислення студентів, формує знаннєвий конгломерат, сукупність безсистемних фактів. Водночас завданням фундаментальної освіти є створення умов для розвитку професійного мислення та саморозвитку і самоосвіти фахівців. При цьому пріоритетними $\epsilon$ фундаментальні знання, що сприяють цілісному сприйняттю навколишнього світу, особистісному розвитку студента та адаптації фахівця до умов професійної діяльності.

Головна ознака кризи вищої освіти, у тому числі й технічної, полягає не у відриві від передового виробництва і досягнень науково-технічної революції, а в іï декультуризації. Криза освіти - це криза гуманістичної традиції розглядати людину як мету, а не як засіб. Головною функцією вищої школи має стати розвиток особистості, а не лише підготовка кадрів, аби освіта не зводилась лише до спеціального навчання. Чисто функціональний підхід до людини-спеціаліста неминуче породжує таке ж функціональне відношення до природи, як до справжнього ресурсу, що підлягає освоєнню. Крім того, традиційне виробництво є відчуженим від наукових принципів, не стимулює освіченість, а лише потребує дипломованих спеціалістів. У такій ситуації освіта перетворюється на примусову працю із запам'ятовування вузькоспеціальних знань, потрібних лише для роботи. У педагогічній практиці освіта як єдність навчання і виховання спрощується до простої ретрансляції знань і нав'язування виховних заходів.

Культурологічні дисципліни мають озброювати педагогів методологією наукового бачення вихованця і вихователя як учасників виховного процесу, суспільного і природного середовища як умов виховання, соціалізації як процесу взаємодії людини і суспільства з освоєнням цінностей, культури, традицій, моделей освіти і виховання як механізмів соціалізації у їх взаємодії з іншими інститутами й механізмами.

Висновки. Архетип педагогічної школи академіка Н. Г. Ничкало як парадигма культурологічної освіти у системі педагогічної інноваційної професійної школи - це поворот до людини в навчальних закладах (як до студента, так і до викладача). Сенс повороту - врахування інтересів особистості, створення максимально сприятливих умов для формування ії̈ життєвої та професійної компетентності. Метою освіти стає не просто набуття інформації, а розвиток і саморозвиток особистості. Якщо метою гуманізації $є$ реформування суб' єкта, перетворення студента із пасивного спадкоємця інформації на особистість, творця, то метою гуманітаризації є оволодіння культурою. Знання без трансляції ціннісного ставлення до них є мертвими, а згодом і небезпечними, і тільки культура формує ціннісні орієнтації людини, суспільства.

Таким чином, на прикладі наукової школи академіка Н. Г. Ничкало ми бачимо, що сформований у сучасному класичному мистецтві метафоричний архетип філософії буття як постійного навчання та самовдосконалення має визначальний вплив на формування парадигми культурологічної освіти у системі педагогічних інновацій сучасної освіти. 
Використана література:

1. Культурологія : підручник / за ред. Н. Г. Багдасарян. Москва, 2007. С. 139.

2. Бальзак де Оноре. Думки про мистецтво. Київ : Мистецтво, 1981. 253 с.

3. Бех І. Д. Духовна особистість у контексті освітніх викликів. Рідна школа.2019. № 1. С. 3-7.

4. Загаєвський А. У чужій красі. Кальварія, 2008. 190 с.

5. Ковальчук Г. О. Активізація навчання в економічній освіті : Навчальний посібник. Вид. 2-ге, доп. Київ : КНЕУ, 2003. $298 \mathrm{c}$.

6. Канарский А. С. Диалектика эстетического процесса. Киев : Философия и культура, 2008. 380 с.

7. Мистецтво у розвитку особистості : монографія / Ничкало Н. Г., Зязюн I. А., Отич О. М., Соломаха С. О., Сотська Г. І., Вовк М. П., Попик О. І., Філіпчук Н. О., Чембержі М. І., Харченко П. В., Ніколаї Г. Ю. Чернівці : Зелена Буковина, 2006. $224 \mathrm{c}$.

8. Морева Н. А. Педагогика среднего профессионального образования : учебное пособие. Москва : Издательский центр «Академия», 2001. 272 с.

9. Х Хайдеггер М. Искусство и пространство. Самосознание культуры и искусства ХХ века. Москва, 2000, 546 с.

\section{References:}

1. Bech I. D. (2019) Dykhovna osobustist u konteksti osvitnikh vyklykiv / Ridna shkola. 2019, N. 1. S. 3-7 [Bech I. D. «Spiritual personality in the context of educational challenges». Ridna shkola. 2019, No.1. P. 3-7] [in Ukrainian]

2. Balzac de Honore. Thoughts on Art. Kyiv : Art, 1981. 253 p.

3. Zagayevsky A. In another's beauty. Calvary, 2008. 190 p.

4. Kovalchuk G. O. Reinforcing learning in economic education: Educ. Tool. Kind. 2nd add. K. : KNEU, 2003. 298 p.

5. Canary A. S. Dialectics of the aesthetic process. Kyiv, Philosophy and Culture, 2008. 380 p.

6. Art in personality development: [monograph / Nichkalo N. G., Ziazun I. A., Otych O. M., Solomakha S. O., Sotskaya G. I., Vovk M. P., Popik O. I., Filipchuk N. O., Chambery M. I., Kharchenko P. V., Nikolai G. Y.]. Chernivtsi: Green Bukovina, 2006. $224 \mathrm{p}$.

7. Moreva, N.A. Pedagogics of secondary vocational education: A textbook for students of higher pedagogical institutions. Moscow : Publishing Center «Academy», 2001. 272 p.

8. Heidegger M. Art and space. Self-consciousness of culture and art of the XX century. Moscow, 2000, $546 \mathrm{p}$.

Yakubovska M. S., Budzinska V. M. Conceptual and aesthetic principles of scientific school academician N. G. Nychkalo: cultural aspect

On the example of research of conceptual foundations of the scientific-pedagogical school of academician N. G. Nychkalo the system of conceptual and pedagogical foundations of the Academic School of academician N. G. Nychkalo. The conducted research makes it possible to claim that an important means of forming the personality of a modern specialist is the cultural component. The study of the algorithm of scientific-theoretical aspects of innovative changes in the higher education system shows that the humanitarian security of society depends on the development of the innovative component of modern higher education institutions. Pedagogy, while performing its historical tasks, creates the preconditions for the approval of qualitative innovative processes of pedagogical interaction.

Ukraine's accession to the world educational and economic community, the globalization of the world economy necessitates changes in the nature of vocational education - in its orientation, goals, content - increasingly explicitly orienting it to the creative development of the person, to the creative initiative, independence, competitiveness, mobility of future specialists.

On the example of research of the experience of the scientific-pedagogical school of academician N. G. Nychkalo the algorithm of systemic processes, based on the formation of students 'communicative competence, the systematic evolutionary understanding of the discourse of modern education and the provision of varied technologies of students' cultural education are outlined.

For the successful realization of the tasks of modern personally oriented education, it is important to form the cultural competence of the pupils, which forms the basis of the humanitarian security of the present, the components of which are the information and psychological security of the modern society. The harmony of the society depends on the harmonious formation of the individual at all stages of the educational activity. In these processes it is important to study the scientific and theoretical aspects of the formation of the algorithm of innovative changes in the system of modern education.

Key words: cultural competence, cultural worldview, scientific discourse, discourse invariance, cultural consciousness, art of communication, cultural environment, psychological protection of personality, communicative competence, paradigm of cultural interaction. 